\title{
The aftermath of the Sturtian glaciation: Reconstructing palaeo- seawater chemistry and silicate weathering.
}

\author{
HOLLY L. TAYLOR ${ }^{* 1}$, ANTHONY DOSSETO ${ }^{1}$, JURAJ \\ FARKAŠ ${ }^{2,3}$, GRANT COX, KELSEY LAMOTHE ${ }^{4}$
}

${ }^{1}$ University of Wollongong (*correspondence: hlt434@uowmail.edu.au)

${ }^{2}$ University of Adelaide

${ }^{3}$ Czech University of Life Sciences

${ }^{4}$ McGill University

The Cryogenian marks a crucial time in Earth's history, with significant climatic change characterized by global glaciations and the emergence of metazoan organisms. Dolostones deposited in South Australia and Namibia during the aftermath of the Sturtian glaciation, also known as 'cap carbonates', can be used as a potential archive for environmental change throughout the Neoproterozoic. The deglaciation of such a large glacial event undeniably impacted both the climate and the chemistry of oceans, which could have contributed to the potential biological shift from phototrophic bacteria to planktonic algae.

In this study, we use lithium isotopes $\left(\delta^{7} \mathrm{Li}\right)$ as a proxy for continental silicate weathering, as they fractionate during clay-water interaction. The $\delta^{7} \mathrm{Li}$ values in carbonates especially cap carbonates preserve the chemistry of the oceans, allowing us to investigate environmental changes and elemental fluxes into the oceans during the aftermath of the Sturtian glaciation. We examine this using a box model approach for the oceanic Li cycle, to identify whether there was a period of intense silicate weathering during deglaciation of the Sturtian glaciation, and to determine if it may have caused an extensive riverine flux of continentally derived elements to the oceans, potentially triggering this biological shift.

The $\delta^{7} \mathrm{Li}$ values measured throughout the Sturtian cap carbonates from South Australia (SA) ranged from 9 - 17 $\%$, which are consistant with the ranges in values seen from the Marinoan cap carbonates previously measured ( 6 - 14 $\%$ ). These results demonstrate a consistant variation throughout the deposition of the Sturtian cap carbonates, similar to that seen in the Marinoan. This leads to the conclusion that there was potenually a rapid recovery of the ocean chemistry from the glacial oceans back to somewhat normal or modern ocean conditions. 